\title{
Strategic Options for the Expansion of South African Retail Businesses within Africa: Consequences on Operational Management
}

\author{
*Edward A.N. Dakora, Andrew Bytheway, André Slabbert \\ Cape Peninsula University of Technology, South Africa \\ *dakorae@cput.ac.za
}

\begin{abstract}
The expansion of retail companies across national borders is a global phenomenon that is becoming a reality in Africa. This phenomenon is led largely by South African retailers as they seek new markets in Africa. The continent presents both market opportunities as well as challenges. Yet there has been limited academic research on the management of the complexities faced by these retail companies. This paper examines the strategic options available to senior retail management regarding entry mode choices and the possible factors that influence management decisions as they expand their business activities into Africa. The paper also attempts to echo the consequences of such strategic decisions on operational management when it comes to managing operations abroad. It does so by employing mixed method approaches which include analysis of in-depth interviews with senior managers of five major South African retailers, and results of an online survey of retail workers in Cape Town, using the Principal Component (factor) Analysis technique in SPSS. This resulted in six broad factors which appear to provide unique insight on issues that affect the entry mode choices of South African retailers seeking new markets in Africa. The paper concludes that retail managements making this move are often caught up between management self-confidence and their ability to manage risk.
\end{abstract}

Keywords: Retail business, internationalisation, entry mode, south Africa, African market, risk

\section{Introduction and background}

In the wake of Africa's retail revolution, South African retailers such as Shoprite, Massmart, Woolworth, Truthworths, Mr Price and others have been among the forerunners in taping into the continent's "difficult but lucrative market". However, as Accenture (2009) indicated, it was just a matter of time before the South African retailers investing in the African continent met tough competition from global contenders. This has become the reality as Carrefour increases it presence in Africa and Walmart makes further inroads through its South African subsidiary, Massmart. The extent of retail activity in Africa has prompted the World Retail Congress (an event management company) to shift its attention to the continent by organising for the first time, the World Retail Congress Africa in Johannesburg, South Africa, in November 2013 (World Retail Congress, 2013). This event brought together global, regional and local retail leaders, and leaders of contiguous industries to discuss the market potential of Africa, and how to tap into it. Retailing has become a global phenomenon, and retailers can no longer rely solely on their home country markets for survival because they run the risk of having to compete with global contenders even in their own backyards. As Park and Sternquist (2008) observe, global retailers' segment of customers have similar needs, behaviours and expectations, making them independent of any one country; therefore, these retailers expand into cities where such similarities might be found. This is even more possible with the increase in Internet and mobile technology usage by both retailers and customers, and the social change in which customers are now moving into the formation of "virtual communities" (Pentina, Prybutok \& Zhang, 2008:114). Nevertheless, the process of retail internationalisation is quite complex and dynamic with activities involving sourcing products internationally, operating shops in foreign countries, using foreign labour, adopting foreign ideas and using foreign capital (Dawson \& Mukoyama, 2006). Moreover, it involves the entry mode which has been historically identified as a frontier issue (Wind \& Permutter, 1977). The choice of entry mode still remains one of the most critical and strategic decisions which has to be made by companies planning to expand into foreign markets (Kumar \& Subramaniam, 1997, Hough, 2007, Ripollés, Blesa \& Monferrer, 2011). This adds to the complexity of the internationalisation process, especially in Africa where the markets largely remain fragmented and less structured. 
In Africa, the phenomenon of retail internationalisation is still new, and the experience has been to a greater extent one-sided as this phenomenon is led by South African retailers. However, the factors that influence their entry mode decisions and choices are not clearly understood by many. More so, as to whether or not the choice of entry mode directly or indirectly affects the operations of these business is still not clear. In a review of the Africanisation of South African retailing, Dakora, Bytheway \& Slabbert (2010) propose that due to the challenges in exploring African markets, the choice of entry mode must leverage (1) support for local (host country) economies, (2) supply chain efficiency, (3) border crossing and customs related issues, (4) international competition, and (5) government policies and regulations. These issues are further discussed in Dakora and Bytheway (2012) and Dakora (2012). This paper examines the strategic options, particularly entry modes available to retailers and the factors that appear to influence the entry mode choices of South African retailers expanding into other African countries. Furthermore, it seeks to establish whether the strategic choices made by retail management in this regard, have any impact on their operations abroad. It is important to note that there are different types of retailers and therefore the experiences in this regard might be different. However, this paper concentrates on the South African retail industry generally, with a mix of different retailers. The rest of the paper is structured as follows: first some theoretical background on entry mode research, followed by methodology, analysis of results, discussion, and conclusion, limitation and suggestions for future research.

\section{Theoretical perspective of entry mode research}

A mode of international market entry is defined as an institutional arrangement that allows the product and services, technology, human skills, management, capital and other resources of a company to enter into a foreign country (Root, 1994). Similarly, Kumar and Subramaniam (1997) see it as the international arrangement chosen by a company planning to enter or operate in a foreign market. The dilemma of entry mode choice has been the focus of some of the theories of international business research for a long time, but this is likely to continue as new regions open up for international business. Traditional theories in the study of international business have been used to explain foreign market entry mode choice albeit predominantly from a manufacturing perspective. Some of the most popular theories are indicated here, which can be referred to for more details. These include the eclectic paradigm or OLI framework (Dunning, 1988) which explains the entry mode decision based on three broad factors: ownership advantages (O), location advantages (L) and internalisation advantages (I). Transaction cost theory has also been used to study entry mode choice (see Anderson \& Gatignon, 1986; Erramilli \& Rao, 1993). Additionally, the process of internationalisation and the decisions around that have been critical to successful international expansion. The stages theory (Johanson \& Wiedersheim-paul, 1975; Johanson \& Vahlne, 1977; Johanson \& Vahlne, 2009) explains the characteristics of the internationalisation process of the multinational company with particular attention to decisions that lead to international expansion and resource commitment. However, the dynamics and complexities of entry modes appear much more numerous when it comes to retail internationalisation, and especially in Africa, where the retail firms have limited international experience.

Entry mode options for retail internationalisation: International market entry modes have been classified into two primary categories including wholly owned operations (acquisitions or green fields) and collaborative operations (joint ventures or strategic alliances), with the exclusion of exporting (Kathuria, Joshi \& Dellande, 2008). However, earlier categorisation by Root (1994) clustered entry modes on the basis of export, contractual and investment. The differences in the categorisation of entry mode indicate that entry mode options are to some extent industry specific, and therefore, their completeness in any particular instance becomes problematic. Consequently there are always limited entry mode options available to management when it comes to international market entry strategies (Javalgi, Dixit, Deligonul \& Cavusgil, 2011). The most common entry mode options in retail internationalisation include wholly owned-subsidiaries (which includes mergers and acquisitions) and franchising.

Factors influencing entry mode choice in retail internationalisation: The nature of a company's operation in a foreign market is dependent on the mode chosen for entering that particular market (Kumar \& Subramaniam, 1997:53; Benito, Pedersen \& Petersen, 1999). Consequently, the choice of entry mode is possibly the most important strategic decision any company planning to expand into foreign markets has to make (Kumar \& Subramaniam, 1997; Hough, 2007; Ripollés, Blesa \& Monferrer, 2011). 
This decision is an outcome of analysis of various conflicting factors (including risks and benefits), making it a more difficult one (Anderson \& Gatignon, 1986; Picot-Coupey, 2006). The seriousness of the entry mode decision is further reiterated by Petrou's (2009:615) argument that "...over-investing in foreign market resources via an acquisition, or establishing a start-up that is unable to create an adequate presence to exploit local opportunities - can have serious consequences". The choice of entry mode is influenced by resource commitment, risks and potential benefits, and this is what has led to emphasis being placed on the size and age of companies expanding abroad to the neglect of other external factors (Benito et al., 1999; Ripollés, Blesa \& Monferrer, 2011). Erramilli (1991) found that while international experience plays a role in entry mode choice, diversity of the experience ensures more effectiveness in the process especially when entering culturally distant markets. As Slangen \& Hennarts' (2007) posit, resources and capabilities of the multinational companies (MNCs) are essential when it comes to entry mode choice. It is therefore assumed that MNC's with managerial experience are more likely to choose Greenfield as their mode of entry while those short of these resources would often make acquisitions or enter into other forms of contractual arrangements (Slangen \& Hennart, 2007). Also, Dow and Larimo (2011) found experience, both locally and internationally to play an important role in making the entry mode choice. On the issue of resource availability, Park and Sternquist (2008) argue that a retailer's entry mode choice is contingent upon its assortment of resources.

In general, authors have summarised the factors that must be considered by MNCs when making entry mode decisions into four different groups. Root (1998) and later Hollensen (2007) categorised these factors into: 1. internal factors, which include all management and product related issues, 2. external factors (all macro or environmental issues); 3. Characteristics of the entry mode; and 4. Transaction related issues. Internationalising retailers have to deal with factors emanating from all these four categories. Therefore, for a company to compete in a foreign country with the host country firms in their own markets, it "must possess superior assets and skills that can earn economic rents that are high enough to counter the higher cost of servicing these markets" (Agarwal \& Rasmaswami, 1992:4). Also, in their study of company board characteristics and choice of entry mode, Datta, Musteen \& Herrmann (2009) found that board characteristics have an important influence on the choice between acquisitions and joint-ventures when it comes to international expansion. The authors of this paper aver that structural composition of a company's board can lead to opportunistic or risk aversive behaviours on the part of managers if there is no monitoring system.

\section{Methodology}

Mixed methods research in context: Research in the international business domain and management sciences in general has, in history, always favoured the quantitative paradigm, a position taken based on the qualitative-quantitative debate of the 1970s and 1980s (Sale, Lohfeld \& Brazil, 2002). This instigated an early concern by McDonald (1985) that the preference of top-tier journals in the international business domain for quantitative studies can lead "researchers in international marketing to trivialise their findings either by applying a quantitative technique to a topic for which it is not appropriate or by selecting a topic that is quite suitable for quantitative analysis but is itself trivial". Following this debate over qualitative and quantitative approaches to research, there has been an increasing adoption of mixed methods as a form of research that could potentially resolve the longstanding academic conflict. Since the beginning of the 20th century, management researchers have started exploring the potential of mixed methods research, leading to the current situation where there are "three methodological or research paradigm worlds, with quantitative, qualitative, and mixed methods research all thriving and working together" (Johnson, Onwuegbuzie \& Turner, and 2007:117). This paper reports the results of both qualitative and quantitative data.

Interviews: The design of this study included both qualitative and quantitative streams. In this regard, in-depth interviews were conducted with senior managers from five major South African retail companies, all of which have operations in other African countries. These include: Shoprite (1 respondent), Pick n Pay (2 respondents), Woolworths RSA (3 respondents), Mr Price (1 respondent), and Foschini (2 respondents). Respondents included directors in all cases who were directly involved or spearheading the expansion of the retailers into Africa. A total of 9 interviews were conducted across all the five retailers. The interviews yielded information that was based on the respondents' experiences, knowledge of the strategic issues and perceptions regarding their expansion into other African countries 
and elsewhere. The interview style was more conversational, with few restrictions and no leading questions involved. This approach allowed for a shared process in which both the researcher and the respondents participated in generating data through the synthesis of verbal interaction and reflection, where both parties discover new aspects of the phenomenon (Krauss, Hamzah, Omar, Suandi, Ismail, Zahari \& Nor, 2009:248). The information was recorded with on a voice recording devise, transcribed and coded into an in-house developed Qualitative Content Analyser (see Bytheway, 2013) for analysis. The content analysis technique allowed for the transcript data to be broken into specific items, evidencing "chunks" of texts, categories, and constructs (referred to by Schutz, 1959) as "denotata" that emerged from the analysis.

Supplementation by means of quantitative survey: Apart from the interviews, a survey was conducted among a purposive sample of retail workers in South Africa. The intention was to get different views from a mix of people in the retail industry on the phenomenon, ranging from senior management to flexible staff. The survey was designed in Lyme Survey (the online survey tool), and a link was sent by E-mail to an initial total number of about 200 contacts, with invitation to forward it to their colleagues and whoever else they knew in the industry. So there was no control over how many people actually received the survey. But, because the responses were recorded in Lyme Survey the key measure was the number of people who attempted and/or completed the survey. In this process, 72 out of 82 attempts were fully completed and submitted. Ten responses were started but never completed. The data were then exported from Lime Survey into SPSS for analysis. The Principal Component (factor) analysis was conducted within SPSS to reduce and group the variables in the data into factors and triangulated with the interviews to provide some meaning and understanding of the phenomenon under study.

\section{Results}

Interviews: The interviews were transcribed verbatim and the data was analysed using a Microsoft Access based "qualitative content analyser" (see Bytheway, 2013) designed around the principles of qualitative analysis originally articulated by (Schutz, 1959) and developed subsequently by others (Strauss \& Corbin, 1998). The content of the interviews was loaded into the database and deconstructed into categories, constructs and chunks of text. A total of 19 general categories were identified based upon which five key categories were established to serve the purpose of this study. Figure 1 presents a frequency distribution of key categories from the interviews.

\section{Figure 1: Frequency distribution of key interview categories}

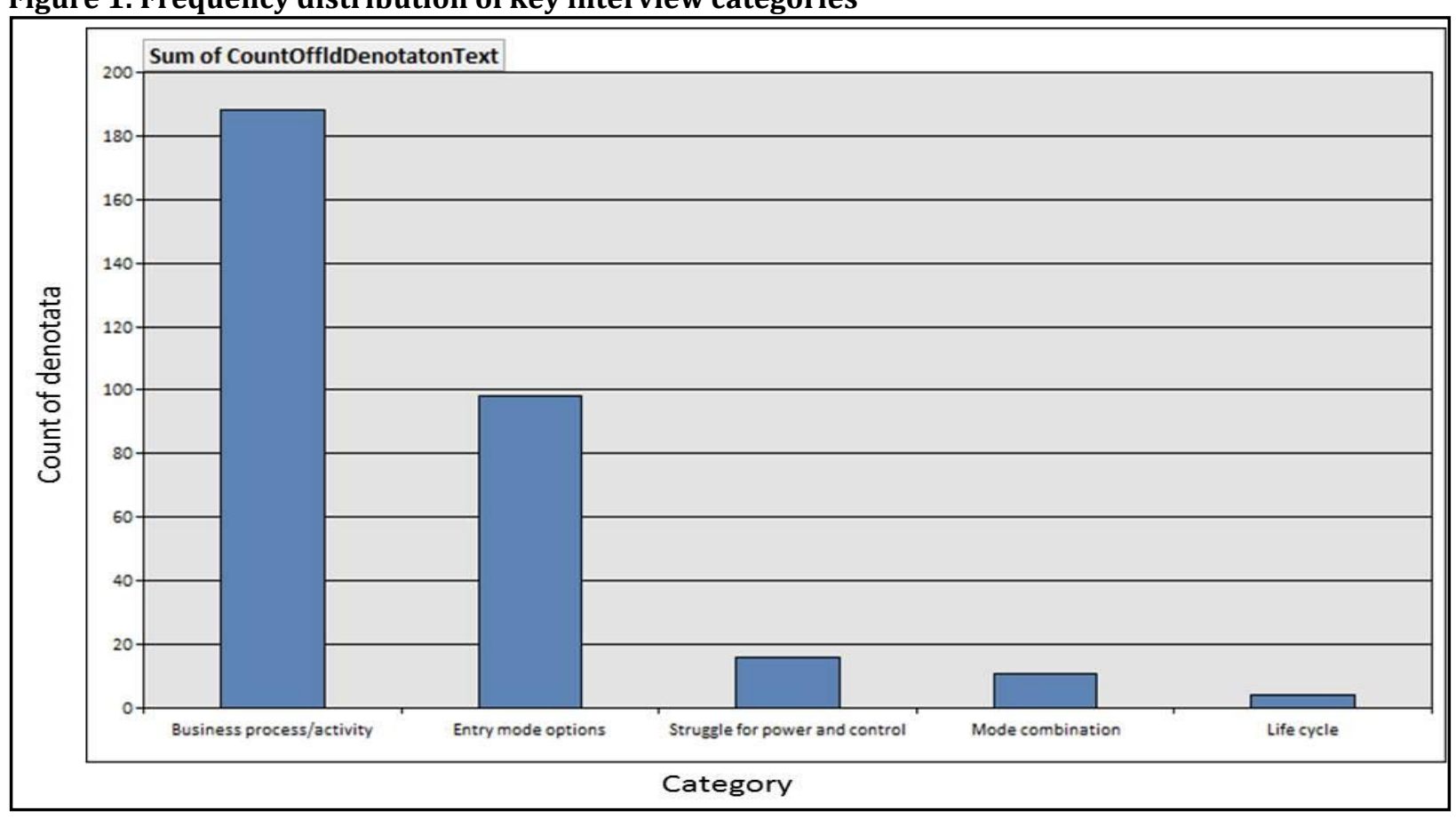


It is interesting to find that issues around business process and activities dominated the interview as illustrated by Figure 1. Despite the strategic importance of business expansion and entry mode choice, the retailers studied appear to be more concerned about the business processes and the activities involved in this process to make their businesses work abroad. In effect, getting to understand the different African countries and the complexities of doing business in these countries before extending their business operations there has been placed even at a much higher level on their agendas than the choice of entry mode itself. Table 1 provides some details from the interviews on these key categories.

Table 1: Summary of interviews by retailers and key categories

\begin{tabular}{|c|c|c|c|c|c|}
\hline $\begin{array}{l}\text { Retailer } \\
\text { Category }\end{array}$ & Woolworths & Mr Price & Foschini & Shoprite & Pick n Pay \\
\hline $\begin{array}{l}\text { Entry } \\
\text { mode } \\
\text { options }\end{array}$ & $\begin{array}{l}\text { - Own } \\
\text { stores/ } \\
\text { greenfield } \\
\text { - } \quad \text { Distrib } \\
\text { ution } \\
\text { arrangement } \\
\text { - } \quad \text { Franchi } \\
\text { sing }\end{array}$ & $\begin{array}{ll}\bullet & \text { Franch } \\
\text { ising } & \end{array}$ & $\begin{array}{ll} & \text { Franchisi } \\
\text { ng } & \\
\bullet & \text { Own } \\
\text { stores } & \text { greenfield }\end{array}$ & $\begin{array}{l}\text { - Own } \\
\text { stores/ } \\
\text { greenfield } \\
\text { - Partne } \\
\text { rship }\end{array}$ & $\begin{array}{l}\text { - Own } \\
\text { stores/ } \\
\text { greenfield } \\
\text { sing Franchi }\end{array}$ \\
\hline $\begin{array}{l}\text { Business } \\
\text { process } \\
\text { and } \\
\text { stages }\end{array}$ & $\begin{array}{l}\text { - Gone } \\
\text { through phases } \\
\text { - Started } \\
\text { by test the } \\
\text { market } \\
\text { - Follow } \\
\text { ed by actual } \\
\text { expansion }\end{array}$ & $\begin{array}{l}- \text { Detaile } \\
\mathrm{d} \text { evaluation of } \\
\text { the city } \\
\text { - Literall } \\
\text { y walk the } \\
\text { pavement } \\
\text { - Check } \\
\text { competition } \\
\text { - Cross } \\
\text { matrix } \\
\text { comparison }\end{array}$ & $\begin{array}{l}\text { Follow a } \\
\text { checklist } \\
\text { - Walk the } \\
\text { streets to } \\
\text { understand } \\
\text { to people } \\
\text { - Vpeaking } \\
\text { the Visiting } \\
\text { countries. target }\end{array}$ & $\begin{array}{l}\text { - A } \\
\text { combination of } \\
\text { things happen } \\
\text { - Send a } \\
\text { team to } \\
\text { evaluate the } \\
\text { country } \\
\text { - Presen } \\
\text { ts to the board } \\
\text { and the process } \\
\text { continues until } \\
\text { a decision is } \\
\text { made }\end{array}$ & $\begin{array}{l}\text { - } \\
\text { ation } \\
\text { - } \\
\text { not understood } \\
\text { - } \quad \text { Decided } \\
\text { to gain } \\
\text { experience in } \\
\text { Australia first } \\
\text { - Time to } \\
\text { look at the rest } \\
\text { of Africa }\end{array}$ \\
\hline $\begin{array}{l}\text { Mode } \\
\text { change/ } \\
\text { combinat } \\
\text { ion }\end{array}$ & $\begin{array}{ll}\bullet & \text { Mode } \\
\text { change } & \end{array}$ & $\begin{array}{l}\text { - Possibi } \\
\text { lity of mode } \\
\text { change }\end{array}$ & $\begin{array}{l}-\quad \text { Possibilit } \\
\text { y of mode change } \\
\text { - } \quad \text { Possibilit } \\
\text { y of joint venture }\end{array}$ & $\begin{array}{l}-\quad \text { Mode } \\
\text { change }\end{array}$ & $\begin{array}{ll}\bullet & \text { Mixed } \\
\text { modes } & \end{array}$ \\
\hline $\begin{array}{l}\text { Struggle } \\
\text { for power } \\
\text { and } \\
\text { control }\end{array}$ & $\begin{array}{l}\text { - Issues } \\
\text { of "Big Brother" } \\
\text { • } \\
\text { nce from local } \\
\text { population } \\
\text { - } \quad \text { Owners } \\
\text { hip issues }\end{array}$ & & & $\begin{array}{l}\text { - Does } \\
\text { not mix } \\
\text { business with } \\
\text { politics } \\
\text { the rules of the } \\
\text { land }\end{array}$ & $\begin{array}{l}\text { - Local } \\
\text { authorities have } \\
\text { their own } \\
\text { development } \\
\text { agenda }\end{array}$ \\
\hline Lifecycle & $\begin{array}{l}\text { - Things } \\
\text { can change } \\
\text { - } \quad \text { Franchi } \\
\text { sing is the best } \\
\text { when it comes } \\
\text { to withdrawal }\end{array}$ & & $\begin{array}{l}\text { - Compro } \\
\text { mising on market } \\
\text { knowledge can } \\
\text { lead } \\
\text { failure/exit }\end{array}$ & $\begin{array}{l}-\quad \text { If the } \\
\text { rules are not } \\
\text { favourable they } \\
\text { exit }\end{array}$ & \\
\hline
\end{tabular}

Factor Analysis: In the process of performing factor analysis in SPSS, the 19 items or variables were correlated using the Principle Component method, Eigenvalue test, and Varimax rotation. Only the Varimax rotation statistics based upon which the factors are determined are presented here due to space constrains. A reliability test of the data was carried out is SPSS to establish the consistency among the items before factor analysis. This test of reliability, using Crombach's Alpha technique, recorded an Alpha 
value of 0.74 , indicating a high-level of consistency among the variables or items (see Table 2). Yet again, a KMO measure of sampling adequacy is 0.6, and Bartlett's test of significance which sought to establish the significance of the data reported a very high significance level $(p<0.001)$ (see Table 3$)$. The results these tests (reliability, sampling adequacy and significance) are satisfactory and confirm that factor analysis is suitable for this data, because the variables or items correlate in a way that item grouping could be computed to represent factors (see Burns \& Burns, 2009).

Table 2: Reliability test

\begin{tabular}{ll}
\hline $\begin{array}{l}\text { Cronbach's } \\
\text { Alpha }\end{array}$ & N of Items \\
\hline .740 & 19 \\
\hline
\end{tabular}

\section{Table 3: KMO and Bartlett's test}

\begin{tabular}{lll}
\hline Kaiser-Meyer-Olkin Measure of Sampling Adequacy. & .601 \\
Bartlett's Test of Sphericity & Approx. Chi-Square & 379.537 \\
& Df & 171 \\
& Sig. & .000 \\
\hline
\end{tabular}

The degree of consistency among the variable is significant, especially in that the number of items in this scale is only nineteen, and the Alpha value is influenced by the number of scaled items and usually increases as the number of items increases. Given the acceptable level of reliability of the data based on the Alpha value of 0.740 , it can be assumed that all the items or variables are homogeneous and measure the same construct.

Table 4: Factor items and their loadings

\begin{tabular}{|c|c|c|c|c|c|c|c|c|}
\hline \multirow[b]{2}{*}{$\mathbf{N}$} & \multirow[b]{2}{*}{ Item } & \multirow[b]{2}{*}{$\begin{array}{l}\mathbf{Q} \\
\text { No }\end{array}$} & \multicolumn{4}{|c|}{ Factor Loading } & \multirow[b]{2}{*}{ F5 } & \multirow[b]{2}{*}{ F6 } \\
\hline & & & F1 & F2 & F3 & F4 & & \\
\hline \multirow[t]{2}{*}{1} & Our company is the right size to go into Africa. & q1. & 0.8 & & & & & \\
\hline & & 1 & 50 & & & & & \\
\hline \multirow[t]{2}{*}{2} & We have the right resources and capabilities to go into Africa. & q1. & 0.8 & & & & & \\
\hline & & 2 & 58 & & & & & \\
\hline \multirow[t]{2}{*}{3} & Our non-African international experience is appropriate for & q1. & & & & 0.5 & & 0.4 \\
\hline & Africa. & 3 & & & & 20 & & 82 \\
\hline \multirow[t]{2}{*}{4} & Our supply chain and logistics are already appropriate for & q1. & 0.5 & & & 0.5 & & \\
\hline & Africa. & 4 & 00 & & & 17 & & \\
\hline \multirow[t]{2}{*}{5} & Our product mix is suitable for Africa. & q1. & 0.5 & & & & 0.5 & \\
\hline & & 5 & 65 & & & & 14 & \\
\hline \multirow[t]{2}{*}{6} & We do not need advance information systems and technology & q1. & & & & 0.6 & & \\
\hline & to go into Africa. & 6 & & & & 95 & & \\
\hline \multirow[t]{2}{*}{7} & Our expansion into Africa is constrained by financial & q1. & & & & & & 0.6 \\
\hline & considerations. & 7 & & & & & & 72 \\
\hline \multirow[t]{2}{*}{8} & We consider expansion into Africa to be high risk. & q2. & & 0.6 & & & & \\
\hline & & 1 & & 83 & & & & \\
\hline \multirow[t]{2}{*}{9} & Government regulations of African countries prevent us from & q2. & & 0.7 & & & & \\
\hline & doing business in Africa. & 2 & & 72 & & & & \\
\hline 1 & We can mitigate risk by opening our own stores in African & q2. & & & & & 0.8 & \\
\hline 0 & countries. & 3 & & & & & 16 & \\
\hline 1 & We do not need target country suppliers because we already & q2. & & & & & & 0.6 \\
\hline 1 & have suppliers. & 4 & & & & & & 60 \\
\hline 1 & The rest of Africa has different cultures that make it difficult & q2. & & 0.7 & & & & \\
\hline 2 & for us to operate our own stores. & 5 & & 88 & & & & \\
\hline 1 & There is less competition in the rest of Africa which makes it & $\mathrm{q} 2$. & & 0.4 & & & 0.4 & \\
\hline 3 & attractive to us. & 6 & & 58 & & & 58 & \\
\hline 1 & We open our own stores in African countries because we need & q3. & & & & 0.6 & & \\
\hline 4 & to control our business. & 1 & & & & 68 & & \\
\hline 1 & The resource commitment required, affects the way in which & q3. & & & 0.7 & & & \\
\hline 5 & we enter into Africa. & 2 & & & 59 & & & \\
\hline 1 & We look for flexible ways of going into Africa, so that we can & q3. & & & 0.6 & & & \\
\hline 6 & adapt to changing conditions. & 3 & & & 51 & & & \\
\hline 1 & The level of risk involved is critical to the way in which we go & q3. & & & 0.6 & & & \\
\hline 7 & into Africa. & 4 & & & 39 & & & \\
\hline 1 & The way in which we operate in African countries now is & q3. & & & 0.6 & & & \\
\hline
\end{tabular}




\begin{tabular}{llll}
\hline 8 & subject to change in the future. & 5 & 39 \\
1 & We do business in African countries in a way that we can pull & q3. & \\
9 & out easily if necessary. & 6 & 0.5 \\
\hline $\mathrm{N}=72$ & & 09 \\
\hline
\end{tabular}

The results are rotated using the Varimax technique. Factor rotation is done in order to reduce the number of factors on which the items under study record high loadings (Burns \& Burns, 2009). This process did not change the factor matrix but reduced the amount of factor loadings by increasing the larger loadings and decreasing the smaller ones, thereby making the factors less complex and easy to name and interpret. Table 5 presents the rotated results as rotated component matrix.

Table 5: Factor loadings after rotation Rotated Component Matrixa

\begin{tabular}{|c|c|c|c|c|c|c|}
\hline & \multicolumn{6}{|c|}{ Component } \\
\hline & 1 & 2 & 3 & 4 & 5 & 6 \\
\hline $\mathrm{q} 1.1$ & .850 & & & & & \\
\hline $\mathrm{q} 1.2$ & .858 & & & & & \\
\hline q1.3 & & & & .520 & & .482 \\
\hline q1.4 & .500 & & & .517 & & \\
\hline $\mathrm{q} 1.5$ & .565 & & & & .514 & \\
\hline q1.6 & & & & .695 & & \\
\hline q1.7 & & & & & & .672 \\
\hline q2.1 & & .683 & & & & \\
\hline $\mathrm{q} 2.2$ & & .772 & & & & \\
\hline $\mathrm{q} 2.3$ & & & & & .816 & \\
\hline $\mathrm{q} 2.4$ & & & & & & .660 \\
\hline $\mathrm{q} 2.5$ & & .788 & & & & \\
\hline q2.6 & & .458 & & & .458 & \\
\hline q3.1 & & & & .668 & & \\
\hline q3.2 & & & .759 & & & \\
\hline q3.3 & & & .651 & & & \\
\hline q3.4 & & & .631 & & & \\
\hline q3.5 & & & .639 & & & \\
\hline q3.6 & & & & & & .509 \\
\hline
\end{tabular}

Extraction Method: Principal Component Analysis.

Rotation Method: Varimax with Kaiser Normalization.

1. Rotation converged in 7 iterations.

2. Rotation converged in 7 iterations.

During the rotation process, loadings that were reduced below 0.4 have been eliminated from the factor matrix. This is because the cut off point for the inclusion of loading for the purpose of this analysis is 0.4 . Factor 1 recorded 11 loadings with the highest loading of 0.688 in component matrix before rotation. But, the same factor shows a record of only four loadings; less than half of the loadings previously recorded before rotation, but with the highest loading increasing to 0.858 . Also, during the rotation process the factors have shed off some items because their loadings have been suppressed below 0.4 , but the same factors picked up new items with significantly increased loadings. This development has resulted in better combination of items and for that matter more suitable factors that address the research objective. The Principal Component factor analysis process produced six factors. Factor 1 is responsible for the $19.924 \%$ of the variance, which constitutes the highest contribution among the six factors to the total variance. This is so because the Eigenvalues of factors, on which these percentages are based, decrease as the number of factors increase. Furthermore, Factor 2, 3, 4, and 5 contribute $13.048 \%, 8.607 \%, 8.058 \%$, $7.296 \%$ and $5.965 \%$ respectively to the total variance of $62.898 \%$. The remaining factors that are not extracted from this analysis contribute negligible amount of variance and, are therefore, not counted to make any factor. As per Kaiser's rule, only factors with Eigenvalues greater than one are considered. Six factors were rotated, based on the factor loadings starting from 0.4 and above. The minimum loadings were restricted to 0.4 and this is due to the numerical weakness of the sample. 
Interpretation of factors: The factor items which were used as statements on the Likert Scale centred on the company internal or managerial issues, the target country issues and the entry mode related issue, all geared toward the entry mode decision (see Table 4). Although this list of items, which have been summarised from the study of literature of international retailing is not exhaustive, it provides a suitable framework in the context of this study based on which the entry mode choice in the expansion processes of South African retailers can be mirrored. The factors are named on the basis of items with loadings higher than 0.5 as guided by Burns and Burns (2009). However, Burns and Burns (2009) further indicate that in dealing with complex phenomena (like the expansion of South African retailing where the variables involved are not clearly definitive) the naming of factors can be difficult, and sometimes subjective. In this analysis, the first three factors are the critical factors as they load on items closely in line with the research objective: company related issues, target country or market related issues and entry mode related issues respectively. The rest of the factors embody quite a different mix of items that contribute to their meanings. The six factors that emerged are the following:

- $\quad$ Factor \#1: Management self-efficacy

- Factor \#2: Market related challenges to the expansion

- Factor \#3: Entry mode issues

- Factor \#4: Struggle for power and control

- $\quad$ Factor \#5: Mitigation of risk

- $\quad$ Factor \#6: Tolerance to risk

Reconciling the interviews and factor analyses: In order to establish the relationship between the six factors that came out of the quantitative analysis (the survey of perceptions within the retail industry) and the qualitative analysis (interviews with the five retailers), the factors from the statistical analysis of the survey were used to code the retailer interviews. Figure 2 provides a perspective on the behaviour of retailers towards their expansion into Africa, especially in terms of the frequency of reference to topics relating to the six factors from the statistical analysis: there is an overriding interest in their innate ability to "do the business" ("management self-efficacy") and the markets that they are aiming for ("market related challenges"). Other issues appear in the conversations, but it is particularly interesting that issues of risk rank so low in their priorities.

\section{Figure 2: Quantitative factors and their qualitative attributions}

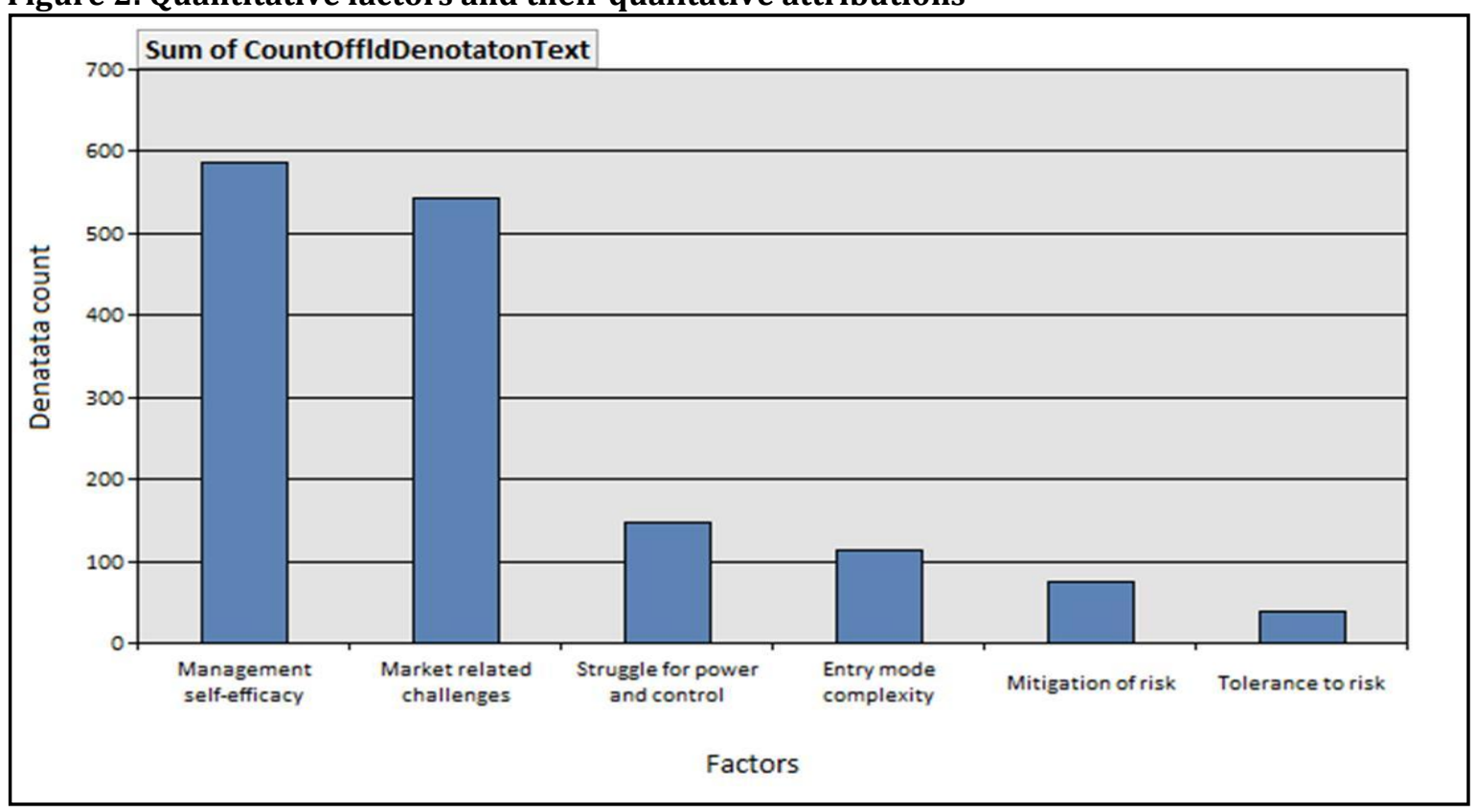

It appears the retailers are more concerned with their ability to deal with real business challenges that might arise from the market itself, rather than other issues that might have political connotations. 
Shoprite states that "the politics doesn't worry us" [Shoprite respondent]. But that is perhaps because they have the appropriate management structure with enough experience to mitigate the risks, as suggested by Erramilli (1991).

Discussion: As this study seeks to establish the entry choices of South African retailers, the factors that influence these choices, and their possible impact on business activities, it is important to look at how the factors presented in Figure 2 correlate with the different entry mode options available to the retailers. Table 6 illustrates a factor - entry mode matrix in which the retailer interview content is mapped with the statistically produced factors.

Table 6: Factor-entry mode matrix

\begin{tabular}{|c|c|c|c|c|}
\hline $\begin{array}{l}\text { Mode } \\
\text { Factor }\end{array}$ & Wholly-owned & Franchised & Joint venture & Strategic alliance \\
\hline $\begin{array}{l}\text { Management } \\
\text { self-efficacy }\end{array}$ & $\begin{array}{l}\text { where there is } \\
\text { sustainable income } \\
\text { Experience } \\
\text { structure } \\
\text { ostablished } \\
\text { of the market } \\
\text { managers making the } \\
\text { deals }\end{array}$ & $\begin{array}{l}\text { Where } \\
\text { there is lack of } \\
\text { understanding of } \\
\text { the market } \\
\text { of Confidence } \\
\text { making the deals }\end{array}$ & & \\
\hline $\begin{array}{l}\text { Market } \\
\text { related } \\
\text { challenges }\end{array}$ & $\begin{array}{l}\text { Where it is } \\
\text { easier and less risky } \\
\text { friendly Investment } \\
\text { different things are the } \\
\text { more difficult it is } \\
\text { Poor quality of } \\
\text { local products } \\
\text { affordable }\end{array}$ & $\begin{array}{l}\text { - Where it } \\
\text { more difficult and } \\
\text { risky } \\
\text { - risky due } \\
\text { to changes in } \\
\text { governments } \\
\text { that want local } \\
\text { ownership } \\
\text { - Poor } \\
\text { quality of local } \\
\text { products }\end{array}$ & $\begin{array}{l}\text { - countries } \\
\text { that want local } \\
\text { ownership } \\
\text { n Franchise } \\
\text { not affordable }\end{array}$ & $\begin{array}{l}\text { - countries } \\
\text { that want local } \\
\text { ownership } \\
\text { n Franchise } \\
\text { not affordable }\end{array}$ \\
\hline $\begin{array}{l}\text { Entry mode } \\
\text { issues }\end{array}$ & $\begin{array}{l}\text { Where we } \\
\text { believe we must go } \\
\text { corporate } \\
\text { - No sharing of } \\
\text { wealth } \\
\text { - More profit }\end{array}$ & $\begin{array}{l}\text { Where we } \\
\text { believe we must go } \\
\text { franchise } \\
\text { market Testing the } \\
\text { - Less capital } \\
\text { requirement } \\
\text { - Less risk }\end{array}$ & & $\begin{array}{l}\text { - Distribution } \\
\text { arrangement/ } \\
\text { agreement }\end{array}$ \\
\hline $\begin{array}{l}\text { Struggle for } \\
\text { power and } \\
\text { control }\end{array}$ & $\begin{array}{l}\text { - Resistance to } \\
\text { big brother } \\
\text { - no corporate } \\
\text { mode in Kenya } \\
\text { - relationship } \\
\text { local government }\end{array}$ & $\begin{array}{l}\text { - Working } \\
\text { through local } \\
\text { companies } \\
\text { - Formalise } \\
\text { retail system }\end{array}$ & $\begin{array}{l}\text { - Working } \\
\text { through local } \\
\text { companies } \\
\text { - Formalise } \\
\text { retail system }\end{array}$ & $\begin{array}{l}\text { - Working } \\
\text { through local } \\
\text { companies } \\
\text { - Formalise } \\
\text { retail system }\end{array}$ \\
\hline $\begin{array}{l}\text { Mitigation of } \\
\text { risk }\end{array}$ & $\begin{array}{l}\text { - Not fixed on } \\
\text { any particular } \\
\text { - Going } \\
\text { cautiously into Africa }\end{array}$ & $\begin{array}{l}\text { - Not fixed } \\
\text { on any particular } \\
\text { mode }\end{array}$ & $\begin{array}{l}\text { Not fixed } \\
\text { on any particular } \\
\text { mode }\end{array}$ & $\begin{array}{l}\text { - } \quad \text { Not fixed on } \\
\text { any particular mode }\end{array}$ \\
\hline $\begin{array}{l}\text { Tolerance to } \\
\text { risk }\end{array}$ & $\begin{array}{l}\text { The politics do } \\
\text { not worry us. } \\
\text { - We look at }\end{array}$ & intolerance & & \\
\hline
\end{tabular}


As has already been shown by Figure 2, management self-efficacy is important for the expanding of South African retailing across national borders. According to Table 6 retailers that are confident tend to either open their own stores or franchise. This position is also reflected in Table 1 where most of the retailers will prefer to have wholly owned operations. For instance, Shoprite, one of the pioneers of the Africa expansion project, makes it clear that:

...if we spend money to build a store now, we will spend it where there is sustainable income, [where] there are minerals or oil [Shoprite Respondent].

We have tried to ensure that we get our home right, that we've gone out and expanded into Australia, and [that] we've got the neighbouring countries. But now it's time to start looking at the rest of the continent and region [Pick $n$ Pay Respondent].

We believe that we understand Southern Africa better than we understand Australia or any of those places. We believe that we will be more appropriate to the African markets [Foschini Respondent].

The resource commitment required in opening own stores makes it necessary for the retailers that choose this mode to have flexibility and control over their processes and procedures, and with international managers making decisions without much local interference (Menipaz \& Menipaz, 2011). It is therefore not surprising that Shoprite only wants to open stores where there is sustainable income. Additionally, it can be deduced that the retail with sufficient management confidence are also more tolerant to risk as reflected by Table 6 . The rest of the factors - market related challenges, struggle for power and control, entry mode issues, and risk mitigation - have been found to influence retailers to consider between own stores, franchising, joint ventures and strategic alliances. As shown in Table 6, these factors generally concern risk, although this is different in different country scenarios. Moreover the results agree in general sense with the broader categorisation of entry mode factors by Root (1998) and Hollensen (2007) including: internal factors (which include all management and product related issues); external factors (all macro or environmental issues); characteristics of the entry mode; and transaction related issues. More specifically, the retailers that are concerned about market related challenges tend to consider wholly-owned stores, franchising, joint ventures and strategic alliances for their entry modes. The following quotes throw more light on this:

... where we believe it will be easier and less risky, we will want to go corporate; where we see things more difficult for all kinds of reasons it could be legal, it could be political, it could be climatic, it could be customs, local customs that may be very different, then we would say the risks there are higher, and franchising will be a safer option, but you make less profit [Foschini respondent].

The biggest problem is the availability of land. Now Ghana, specifically, land issue is a problem; there are cases going in court for the last 10-20 years. You have the same in Nigeria. Every time there is a change in government or a chief, land is allocated to people [Shoprite respondent].

One of the tragedies of Africa is that there is no cooperation between countries to standardise paperwork, processes, import duties and to try and facilitate the easy access of goods to markets. So there are unique challenges in every country in Africa; there is not one of them we can say is easier than the other [Mr Price respondent].

The level at which the retailers manage the challenges posed by the market conditions of target countries determines which entry mode they choose. Apart from the above quotes regarding market related challenges, there are other challenges, such as poor quality of products in the local markets and the cost of franchises that also influence decisions regarding the entry mode. The interviews (Table 1) and the factor analysis (Figure 2) both show that the retailers under study are often engage in the struggle for power and control, and other entry mode issues:

And also, the interesting thing is how the local governments are actually engaging with you as well, because they've also got their own agendas on how they want to promote their countries on that side [Pick $n$ Pay respondent].

It might be worth mentioning that a lot of the complexities in this process are intertwined in the relationship between the retailer and the target country stakeholders. It appears the nature of the target 
country has to be taken into consideration when choosing the entry mode. Besides that, a mode and country mismatch could complicate the expansion process, triggering a heightened power struggle, and this can lead to exit of companies. Therefore, the kind of entry mode chosen can be beneficial or detrimental to the strategic objective of the operations since the mode choice is essentially a trade-off between risks and returns (Anderson \& Gatignon, 1986; Kathuria, Joshi \& Dellande, 2008).

Implementation difficulties: It is evident in the interviews and factors (see Figures 1 and 2) that South African retailers operating in other African countries are driven to be concerned about the complexities of business processes and market related challenges. Interestingly, the challenges of expansion in other African countries as expressed by the retailers studied are generally more focused on the operational issues ranging from systems connectivity, local production and supply, imports and freights, labour issues, and land issues to managing franchisees, supply chains and the complexity of going international, and lack of corporation between countries to reduce import duties and paperwork:

There are challenges in different countries. Mozambique, we sell fresh food in Mozambique, we load a truck at 2:00 in the morning and it's in the stores by 14:00 in the afternoon. We are looking at rail freighting some products to Zambia now, so we are looking at different things to try and alleviate. Ghana is a month [Woolworths SA respondent].

The biggest challenge that we have experienced, strangely enough, has been the supply chain. Trying to get the products to market for the lowest cost possible, in other words not having to be penalised, or paper work that doesn't suit customs officials, [and] finding the cheapest fastest route of getting the products to the marketplace [Mr Price respondent].

The minute you go across border everything changes; you've got to read tickets, you've got to read price, you've got different exchange conversions, you've got different taxes, you've got different currencies, legal, systems, and systems are a big issue for us; we are having difficulty getting our system to be able to handle multiple currencies for example [Foschini respondent].

The biggest area that I see is inconsistent is connectivity. We have the mother ship sitting in South Africa and we have stores, irrespective of whether they are franchised stores or corporate stores, sitting in whatever country. You've to be able to link your system [Pick $n$ Pay respondent].

The challenges have implication on the operational management of these businesses especially where there is no clear strategy to deal with them. Yet at the same time, the retailers investing in the rest of Africa have been criticised by target country authorities for their limited contribution to local economies, despite their potential to inject much-needed capital into such economies to fuel growth (Menipaz \& Menipaz, 2011:359). Furthermore, Miller (2008:36) observed that the South African retail investment in Southern Africa has "followed the path of European colonial traders who inscribed the earlier geographies of retail in the region".

\section{Conclusion, limitation and future research}

This paper presented and analysed by means of factor analysis in SPSS, a survey which took a wider view of the factors that influence South African retailers' entry mode choices as they seek expansion into other parts of Africa. The six factors extracted give a general perspective of management behaviour of South African retail businesses in this regard, but most especially how they want to engage with the new foreign markets by way of entry mode. The factors further indicate that retail managements making this move, are often caught between management self-confidence and their ability to tolerate risk. This is because As Dakora et al. (2010) noted, there are significant challenges emanating from market related issues, brand management, and mode differences. The triangulation of the qualitative and quantitative results reinforced the analysis and makes it clearer that the combination of these factors among other things ought to be taken seriously. The results also allude to the suggestion of Evans, Bridson, Byron \& Medway (2008:260) that "a multitude of factors are likely to play a role in driving both [the] decision and the business strategy adopted in foreign markets". Moreover, the decisions regarding retail expansion across Africa present challenges to operational management ranging from supply chain and logistics, regulations and customs to managing multiple currencies, different languages, and systems and connectivity.

Despite the small number of respondents $(\mathrm{N}=72)$ and the resultant weakness of the data for factor analysis (which arguably demands the minimum of $\mathrm{N}=100$ ), it serves the purpose of this study by providing clear indications of the relationships between the items. A good example here is the work of 
Hudson, English and Dawes (2009) which reported only 36 participants but successfully employed factor analysis to establish the relationships between items and their associated constructs. The advantage of this current study is that the factor analysis is not conclusive on its own, but rather serves as complimentary evidence to a more in-depth content analysis on the phenomenon understudy. This study took a general view of the industry with no specific attention paid to any sector. The focus was on the expansion and the entry mode choice rather than the kind of retailers making this move, which is an important limitation. Future research should compare the different kinds of retailers (food and clothing for example).

\section{References}

Accenture (2009). Expansion into Africa: Challenges and success factors revealed. http://www.accenture.com/SiteCollectionDocuments/PDF/Accenture_Strategy_Expansion_into_ Africa_POV.pdf [20 July 2010].

Agarwal, S. \& Ramanswami, S. N. (1992). Choice of foreign market entry mode: Impact of Ownership, Location and Internalization factors. Journal of International Business Studies, 4, 1-27.

Anderson, E. \& Gatignon, H. (1986). Modes of Foreign Entry: A Transaction Cost Analysis and Propositions. Journal of International Business Studies, 17(3), 1-26.

Benito, G. R. G., Pedersen, T. \& Petersen, B. (1999). Foreign operation methods and switching costs: conceptual issues and possible effects. Scandinavian Journal of Management, 15, 213-229.

Burns, R. B. \& Burns, R. A. (2009). Business research methods and statistics using SPSS. Los Angeles: Sage.

Bytheway, A. (2013). Qualitative research without money: Experiences with a home-grown qualitative content analysis tool. Journal of Community Informatics, 9(4).

Dakora, E. A. N. (2012). Exploring the fourth wave of supermarket evolution: concepts of value and complexity in Africa. International Journal of Managing Value and Supply Chains, 3 (3), 25-37.

Dakora, E. A. N. \& Bytheway, A. J. (2012). The internationalisation of retailing: What makes the African situation different? In Morley, M. J. (Ed.). Management Re-imagined. Programme and Proceedings of the $11^{\text {th }}$ World Congress of the international Federation of Scholarly Associations of Management, Kenny Business School, University of Limerick, 26-29 June 2012. Limerick: Interesource Group.

Dakora, E. A. N., Bytheway, A. J. \& Slabbert, A. (2010). The Africanisation of South African retailing: A review. African Journal of Business Management, 4, 748-754.

Dawson, J. \& Mukoyama, M. (2006). The increase in international activities by retailers. In Dawson, J., Lark, R. \& Mukoyama, M. (Eds). Strategic issues in international retailing. London: Routledge.

Dow, D. \& Larimo, J. (2011). Disentangling the Roles of International Experience and Distance in Establishment Mode Choice, 321-355. doi:10.1007/s11575-011-0080-5

Dunning, J. H. (1988). The eclectic paradigm and international production: a restatement and some possible extensions. Journal of International Business Studies, 19(1), 1-31, Spring.

Erramilli, M. K. \& Rao, C. P. (1993). Service firms' international entry-mode choice: A modified Transaction-Cost Analysis approach. Journal of Marketing, 57(3), 19-38.

Erramilli, M. K. (1991). The experience factor in foreign market entry behaviour of service firms. Journal of International Business Studies, 22(3), 479-501.

Evans, J., Bridson, k., Byron, J. \& Medway, D. (2008). Revisiting retail internationalisation: drivers, impediments and business strategy. International Journal of Retail and Distribution Management, 36(4), 260-280.

Hollensen, S. (2007). Global marketing: a decision-oriented approach. 4th ed. London: Prentice Hall.

Hough, J. (2007). Global marketing strategy. In Venter, D., Erwee, R. \& de Lange. R. Global business environments and strategies: managing for global competitive advantage. Cape Town: Oxford.

Hudson, P., English, L. D. \& Dawes, L. (2009). Understanding preservice teachers' predispositions for teaching engineering education in Australian schools. Proceedings of Australasian Association for Engineering Education Conference, Adelaide, 06-09 December 2009. AAEE: 1-6.

Javalgi, R. G., Deligonul, S., Dixit, A. \& Cavusgil, S. T. (2011). International market re-entry: A review and research framework. International Business Review, 20, 377-393. 
Johanson, J. \& Vahlne, J. (2009). The Uppsala internationalization process model revisited: From liability of foreignness to liability of outsidership. Journal of International Business Studies, 40(9), 14111431.

Johanson, J. A. N. \& Vahlne, J. (1977). The internationalization process of the firm - A model of knowledge development and increasing foreign market commitments. Journal of International Business Studies, 8(1), 23-32.

Johanson, J. A. N. \& Wiedersheim-paul, F. (1975). The internationalization of the firm - Four Swedish cases. The Journal of Management Studies, 7(149), 20-37

Johnson, R. B., Onwuegbuzie, A. J. \& Turner, L. A. (2007). Toward defining mixed methods research. Journal of Mixed Methods Research, 1(2), 123-133.

Kathuria, R. Joshi, M. P. \& Dellande, S. (2008). International growth strategies of service and manufacturing firms: the case of banking and manufacturing industries. International Journal of Operations and Production Management, 28(10), 968-990.

Krauss, S. E., Hamzah, A., Omar, Z., Suandi, T., Ismail, I. A., Zahari, M. Z. \& Nor, Z. M. (2009). Preliminary investigation and interview guide development for studying how Malaysian farmers' form their mental models for farming. The Qualitative Report, 14(2), 245-260.

Kumar, V. \& Subramaniam, V. (1997). A contingency framework for the mode of entry decision. Journal of World Business, 32(1), 53-72.

McDonald, M. H. B. (1985). Methodological problems associated with qualitative research: Some observations and case analysis of international marketing planning. International Studies of Management \& Organisation, 15(2), 19-40.

Menipaz, E. \& Menipaz, A. (2011). International business: theory and practice, London: Sage.

Park, Y. \& Sternquist, B. (2008). The global retailer's strategic proposition and choice of entry mode. International Journal of Retail \& Distribution Management, 36(4), 281-299.

Pentina, I., Prybutok, V. R. \& Zhang, X. (2008). The role of virtual communities as shopping reference groups. Journal of Electronic Commerce Research, 9(2), 114-136.

Petrou, A. P. (2009). Foreign Market Entry Strategies in Retail Banking: Choosing an Entry Mode in a Landscape of Constraints. Long Range Planning, 42, 614-632.

Picot-Coupey, K. (2006). Determinants of international retail operations mode choice: Towards a conceptual framework based on evidence from French specialised retail chains. International Review of Retail and Consumer Research, 16(2), 215-237.

Ripollés, M., Blesa, A. \& Monferrer, D. (2011). Role of international precocity in born global firms. International of Technology Transfer and Commercialisation, 10(3-4), 247-267.

Root, F. R. (1998). Entry Strategies for International Markets. Revised and Expanded. San Francisco: Wiley \& Sons.

Root, F. R. (1994). Entry strategies for international markets. San Francisco. CA: Wiley and Sons.

Sale, J. E. M., Lohfeld, L. \& Brazil, K. 2002. Revisiting the quantitative-qualitative debate: Implications for mixed-methods research. Quality \& Quantity, 36, 53-53.

Schutz, W. C. (1959). On categorising qualitative data in content analysis. Public Opinion Quarterly, 22(4), 503-515.

Slangen, A. \& Hennart, J. F. (2007). Greenfield or acquisition entry: A review of the empirical foreign establishment mode literature. Journal of International Management, 13, 403 - 429. doi:10.1016/j.intman.2007.08.001

Strauss, A. \& Corbin, J. (1998). Basics of Qualitative Research. Thousand Oaks, Sage.

Wind, Y. \& Perlmutter, H. (1977). On The Identification of Frontier Issues in Multinational Marketing. Columbia Journal of World Business, 12(4), 131-139.

World Retail Congress Africa. (2013). The African Retail Revolution Realised. http://www.worldretailcongressafrica.com/ [accessed 15 July 2013]. 
Appendix 1

Item-total statistics

Corrected Item-

Scale Mean ifScale VarianceTotal Cronbach's Alpha if Item Item Deleted if Item Deleted Correlation Deleted

\begin{tabular}{lllll}
\hline $\mathrm{q} 1.1$ & 61.15 & 63.512 & .394 & .722 \\
$\mathrm{q} 1.2$ & 61.11 & 65.480 & .387 & .725 \\
$\mathrm{q} 1.3$ & 62.06 & 64.166 & .304 & .730 \\
$\mathrm{q} 1.4$ & 61.71 & 64.069 & .352 & .726 \\
$\mathrm{q} 1.5$ & 61.19 & 65.933 & .323 & .729 \\
$\mathrm{q} 1.6$ & 62.75 & 65.796 & .181 & .744 \\
$\mathrm{q} 1.7$ & 62.60 & 70.864 & -.036 & .760 \\
$\mathrm{q} 2.1$ & 62.46 & 66.026 & .334 & .728 \\
$\mathrm{q} 2.2$ & 62.54 & 65.266 & .296 & .731 \\
$\mathrm{q} 2.3$ & 62.03 & 66.647 & .287 & .731 \\
$\mathrm{q} 2.4$ & 62.47 & 64.196 & .334 & .727 \\
$\mathrm{q} 2.5$ & 62.74 & 62.901 & .359 & .725 \\
$\mathrm{q} 2.6$ & 62.13 & 60.815 & .520 & .710 \\
$\mathrm{q} 3.1$ & 61.90 & 65.948 & .271 & .732 \\
$\mathrm{q} 3.2$ & 61.89 & 65.706 & .346 & .727 \\
$\mathrm{q} 3.3$ & 61.46 & 65.407 & .362 & .726 \\
$\mathrm{q} 3.4$ & 61.81 & 65.764 & .304 & .730 \\
$\mathrm{q} 3.5$ & 61.86 & 65.530 & .376 & .725 \\
$\mathrm{q} 3.6$ & 62.15 & 64.131 & .335 & .727 \\
\hline
\end{tabular}

